\title{
Emergency Management of Medical Wastewater in Hospitals Specializing in Infectious Diseases-a Case Study on Huoshenshan Hospital
}

Jiajun $\mathrm{He}$

Wuhan Institute of Technology

Shushu Zhao

Wuhan Institute of Technology

Hui Zhang ( $\nabla$ zhangh73@wit.edu.cn )

Wuhan Institute of Technology https://orcid.org/0000-0001-6499-5527

Xiaying Liu

Wuhan Institute of Technology

Qin Li

Wuhan Institute of Technology

Wenxuan Fu

Wuhan Institute of Technology

Changhang Sun

Wuhan Institute of Technology

Research

Keywords: Medical wastewater, Emergency management, Huoshenshan Hospital, Management measures

Posted Date: September 17th, 2021

DOl: https://doi.org/10.21203/rs.3.rs-824051/v1

License: (c) (i) This work is licensed under a Creative Commons Attribution 4.0 International License.

Read Full License 


\section{Abstract}

Background: Medical wastewater from hospitals specializing in infectious diseases is a major health and environmental risk during pandemics. However, few systematic studies on medical wastewater management in hospitals of infectious diseases have been reported. As designated emergency field hospital for the treatment of COVID-19, the Huoshenshan Hospital achieved successful outcomes on emergency management measures of medical wastewater.

Results: The lessons of medical wastwater based on Huoshenshan Hospital can be concluded following four aspects: (1) Emergency management system of medical wastewater based on the "Internet Plus" technology, and other related management schemes and standard systems provided legislative foundation for emergency management of medical wastewater. (2) The three-tier prevention and control system of medical wastewater ensured the discharged wastewater meets water quality standards. The system specifically included the individual seep and leak-proof sealed collection system at the first tier, as well as the enhanced disinfection and moving bed biofilm reactor wastewater biological and chemical treatment technology at the second tier. (3) The study established an effective three-tier accountability system in medical wastewater quality monitoring, data recording, storage, and reporting, as well as data review and filing, especially in continuous data monitoring and dynamic analysis of characteristic indicators. (4) Information disclosure by government and public supervision promoted successful implementation of medical wastewater management and control measures. Based on the results of 212 public questionnaires, we also confirmed that information of the case was open to public and internet users who actively participated.

Conclusion: Our study will provide methodological reference for the emergency management of wastewater in designated infectious disease hospitals in similar situations.

\section{Background}

The novel coronavirus pneumonia (COVID-19) first appeared in Wuhan, China, in December 2020, before spreading rapidly worldwide ${ }^{[1]}$. Currently, there have been more than 35 million COVID-19 cases worldwide, with a mortality rate of more than $2 \%$. The social, economic, and environmental impacts of COVID-19 far exceeded those of the severe acute respiratory syndrome (SARS) epidemic in $2003^{[2]}$. The pandemic has not only interrupted economic development but also posed an unprecedented risk to human health and the ecological environment ${ }^{[3]}$, especially water ecosystems ${ }^{[4]}$. As a result of proper environmental management measures such as emergency wastewater treatment, governmental emergency environmental monitoring, and information disclosure during the pandemic ${ }^{5]}$, adverse impacts to the ecological environment (including surface water quality) in China were avoided ${ }^{6]}$. It was identified that hospital wastewater contains hazardous elements and a wide variety of microbial pathogens and viruses, and this may led to a potential significant risk of public health and environment infection ${ }^{[7]}$. Under the COVID-19 pandemic context in the globe, appropriate management of medical 
wastewater is of great significance to reduce the health risks to the public and environment $[1,7,8]$. Although recent scholars have carried out a variety of studies focusing on the hospital wastewater treatment and related management, still there is no a systematic study concerning emergency management of medical wastewater from infectious disease hospital to date. The goal of the study was to explore emergency management measures of medical wastewater based on a successful case such as Huoshenshan Hospital.

After the outbreak of COVID-19 in Wuhan, the city accomplished an astonishing record-setting project. The Huoshenshan Hospital provided adequate treatment to infected patients and curbed the rapid spread of COVID-19 extremely efficiently with the supplement of existing resources. The establishment of the Huoshenshan Hospital has facilitated Wuhan city to effectively control the pandemic. Existing studies have confirmed that medical wastewater from designated hospitals contained a large number of pathogenic microorganisms and viruses ${ }^{[9,10]}$. As a significant source of pollution, it not only degraded water quality but also posed a threat to the health of the general public and surface aquatic ecosystems by potentially spreading and transmitting coronaviruses [4]. A recent study showed that Hospital wastewater system influent were SARS-CoV-2 RNA positive [11]. However, the transmission pathway and spreading mechanism of COVID-19 in medical wastewater are yet to be elucidated, which increases the difficulty of end-of-pipe treatment ${ }^{[12]}$. Studies have shown that collection and pretreatment of medical wastewater at hospital sources greatly reduced environmental risk ${ }^{[13]}$. Therefore, regulation and treatment of medical wastewater containing SARS coronavirus 2 (CoV-2) at the source are evidently essential in effectively controlling transmission and spreading of the virus. With lessons learned from the SARS outbreak regarding environmental pollution and potential problems caused by inadequate disposal of medical waste ${ }^{[14]}$, simultaneous construction of the Huoshenshan Hospital, corresponding wastewater treatment facilities, and online monitoring stations was carried out to support wastewater treatment capacity ${ }^{[15]}$. To effectively utilize the hospital wastewater treatment monitoring facilities and equipment while promptly eliminating the health and environmental risks associated with wastewater, various measures such as legislation on emergency treatment, effective wastewater treatment technology, monitoring, and management have been proposed and implemented. Additionally, the authorities have completely accommodated information disclosure and public participation. The three-tier prevention and control management of wastewater, especially its multiple strict processes, such as the double intensified disinfection and moving bed biofilm reactor (MBBR) biological and chemical treatment at the second level, have ensured that the water quality of the discharge met corresponding standards [ ${ }^{16]}$. Monitoring data showed that the surface water quality in Wuhan was not negatively affected during the outbreak ${ }^{[17]}$. However, considering the lack of effective emergency regulation and treatment for medical wastewater from hospitals dealing with infectious diseases, the successful regulation and treatment of medical wastewater from the Huoshenshan Hospital undoubtedly provided a paradigm for treating medical wastewater bearing pathogens. The aim of this paper was to analyze some adequate environmental management measures for medical wastewater from hospitals treating infectious diseases during an outbreak, based on a case study on the management and treatment measures for medical wastewater at 
the Huoshenshan Hospital. Hence, according to the case study, this research has combed through and summarized the experiences gained for regulation and management of medical wastewater in the following four aspects: medical wastewater treatment technology, environmental monitoring measures, legislative foundation for wastewater emergency treatment, and information disclosure and public opinions. This is to provide a basis and guidance for emergency regulation and management of hospital wastewater bearing pathogens.

\section{Methods And Data Resource}

This study combines qualitative and quantitative information on Huoshenshan Hospital and medical wastewater management and to highlight the emergency management of medical wastewater aimed at infectious diseases hospital. These include: construction progress of the Huoshenshan Hospital and the four successful management aspects of medical wastewater based on a case study from Huoshenshan Hospital. Information was collected mainly from major media sources (e.g., Xinhua News, Beijing Youth Daily, China News Network, China Environmental News, Chutian Metropolics Daily), official survey data and investigation report from Wuhan Bureau of Ecological Environment, and website of related authorities (e.g., the CCTV international online, the Ministry of Ecology and Environment). Content analysis based on recent references and publications was conducted in order to highlight the effectiveness of emergency measure of medical wastewater for the case study, including reference such as Environ Pollu, J Environ Sci, et al. Please see in Figure S1 in supporting information.

Additionally, as an important management lesson such as public participation regarding the case study, its basic information was obtained via questionnaire survey in May 2020. The questionnaire designed with 8 questions were categorized into three parts: (i) basic characterization of the surveyed students (i.e., ages, regions, education level and occupation, Q1 to Q4; (ii) the behavior of respondents related to public participation, Q5; (iii) the means of public participation and corresponding context on the case study, Q6Q8. In total, data information was analyzed from 212 individuals of different ages, regions, educational levels, and occupations using software excel.

\section{Results And Discussion}

\section{Construction progress of the Huoshenshan Hospital}

In order to respond to the challenge and release the capacity burden of the local hospitals, the Chinese government quickly and temporarily built two designated field hospitals used to treat COVID-19 patients in Wuhan, one of which was named Wuhan Huoshenshan Hospital which was deemed "mission impossible," while it was built in nine days, three days shorter than another hospital named Leishenshan

Hospital ${ }^{[18]}$. With the unfortunate ongoing COVID-19 outbreak throughout the world, some other countries are facing with such similar hospital capacity problems, thus the Huoshenshan Hospital can provide a valuable reference to the development of designated field hospitals in the other countries across the world. The Huoshenshan Hospital is a makeshift emergency modern designated field hospital 
specializing in infectious diseases, similar to the Xiaotangshan Hospital established in Beijing during the 2003 SARS epidemic ${ }^{[19]}$. The designing of the hospital started three days after the city lockdown and successfully completed, and complete HDPE anti-seepage film laying at noon at Jan. 29, to fully carry out the medical supporting facilities and installation work until Feb. 1, and was officially handed over to China's Army Joint Service on Feb. ${ }^{[19,20]}$. Figure 1 presented the specific introduction to the construction of Huoshenshan hospital. The hospital was situated in a sanatorium near Zhiyin Lake in southwestern Wuhan, covers an area of approximately 34,000 square meters, with a capacity of 1,000 beds. It utilizes modern information technology such as $5 \mathrm{G}, \mathrm{Al}$, and Internet of Things (loT) to achieve intelligent security, remote medical consultation, intelligent medical record review, and "contactless" operation and maintenance ${ }^{[21]}$. It is also equipped with a $5 \mathrm{G}$ base station.

\section{Legislative guarantee for medical wastewater emergency treatment}

The SARS outbreak that happened 16 years ago in China served as an alarm. Subsequently, nationwide infrastructure construction has been carried out including of hospitals, hospital wastewater treatment facilities, and municipal wastewater treatment plants, and the wastewater protection and management system has gradually improved. Table 1 shows relevant regulations, ordinances, and technical programs for wastewater from hospitals dealing with infectious diseases, as well as the medical wastewater management system and standards in China. These management systems stipulate the principles, processes, methods, and measures for wastewater treatment and the discharge limits of pollutants from hospitals treating infectious diseases. Emergency construction of the wastewater treatment facilities for the Huoshenshan Hospital during the pandemic was designed in strict accordance with the specifications (HJ 2029-2013) and standards (GB 18466-2005). Tackling the enormous challenge brought up by COVID-19, the legislative branch in China responded quickly, improving the legal structure of the public emergency services in China, especially the regulations related to wastewater from hospitals dealing with infectious diseases. Prior to the pandemic, the medical wastewater in China was discharged directly into the city sewer system, mixed with other wastewater, and finally treated at a wastewater treatment plant, following a regulation and management system similar to the practice in some developed countries such as Australia and Spain ${ }^{22,23]}$. When the pandemic occurred, the Ministry of Ecology and Environment applied the "Internet Plus" to build an online communication platform to connect relevant experts, frontline operators, and ecological and environmental management personnel, developing and promptly releasing the Notice, the Technical Program, and the Monitoring Program upon the completion of the Huoshenshan Hospital based on the summarized experience of medical wastewater regulation and management since SARS. These legal documents proposed the legislative requirements for the regulation and management of medical wastewater at the source, that is, the classification and collection, storage, and treatment, emergency monitoring measures such as of chlorine residual and biological toxicity, and protection from and control of pathogen-bearing wastewater. The requirements specified the characteristics of COVID-19-monitoring indicators and disinfection and sterilization 
treatment criteria to achieve the effective prevention and control of the medical wastewater in the Huoshenshan Hospital within the shortest time frame.

Table 1

China's regulations regarding medical wastewater

\section{Three-tier prevention and management system of medical wastewater}

Since the 2003 SARS outbreak, China has been working on the systematic treatment and management of transmission and spreading routes in wastewater during outbreaks of infectious diseases and has formed a solid three-tier prevention and management system, with strict separation and collection at the source, special treatment at different levels, and discharge at specified standards, as shown in Figure 2.

\section{Tier one prevention and control the source (source collection)}

Given that medical wastewater carrying SARS-CoV-2 risks continuous transmission and spreading of the viruses ${ }^{[24]}$, the wastewater treatment process at the hospital must adopt higher standards than those of ordinary infectious disease hospitals, and strictly prevent and control the source; i.e., the tier-one prevention and control. To eliminate the exposure of wastewater to the ambient air and leaking into underground, the wastewater at the Huoshenshan Hospital was physically isolated and collected in a fully enclosed manner [ ${ }^{25]}$. The foundation of the hospital was fully covered with a layer of high-density polyethylene (HDPE) film to prevent seeping and ensure physical isolation of the aboveground structures from groundwater and soil. Domestic sewage and medical wastewater from infectious disease ward were collected separately, and medical wastewater was delivered separately into sealed storage tanks.

\section{Strict tier-two protection and control (disposal system)}

Generally, medical wastewater was discharged in municipal sewage network without pre-treatment in some countries in the world ${ }^{[1]}$. However, a strict tire-two protection and control disposal system was set up for the medical wastewater at Huoshenshan Hospital to reduce the impact of hospital contaminants before evacuation. The wastewater in the sealed storage tanks at the hospital was then transported by a special pipeline into the medical wastewater treatment system of the hospital, formally entering the strict tier-two prevention and control. During this period, the Huoshenshan Hospital specifically doubled the required wastewater treatment equipment with one set each for use and backup, to achieve "double 


\begin{tabular}{|c|c|c|c|}
\hline $\begin{array}{l}\text { Laws, Regulations, and } \\
\text { Standards }\end{array}$ & $\begin{array}{l}\text { Issuing } \\
\text { Authority }\end{array}$ & $\begin{array}{l}\text { Time of } \\
\text { issuance }\end{array}$ & $\begin{array}{l}\text { Relevant provisions of } \\
\text { wastewater management }\end{array}$ \\
\hline $\begin{array}{l}\text { Technical Guideline for } \\
\text { Hospital Wastewater } \\
\text { Treatment (Environment } \\
\text { Development [2003] No. 197) }\end{array}$ & $\begin{array}{l}\text { Ministry of } \\
\text { Ecology and } \\
\text { Environment }\end{array}$ & $12 / 01 / 2013$ & $\begin{array}{l}\text { Separate medical wastewater from } \\
\text { non-medical wastewater with } \\
\text { different piping systems; required } \\
\text { mandatory septic tanks and } \\
\text { secondary treatment in hospitals } \\
\text { treating infectious diseases; } \\
\text { required pre-disinfection }\end{array}$ \\
\hline $\begin{array}{l}\text { Standards for the Discharge } \\
\text { of Water Pollutants from } \\
\text { Medical Organizations (The } \\
\text { Standards, GB 18466-2005) }\end{array}$ & $\begin{array}{l}\text { Ministry of } \\
\text { Ecology and } \\
\text { Environment }\end{array}$ & 05/17/2005 & $\begin{array}{l}\text { Specify the pollutant discharge } \\
\text { limits in the wastewater from } \\
\text { hospitals dealing with infectious } \\
\text { diseases }\end{array}$ \\
\hline $\begin{array}{l}\text { Engineering and Technical } \\
\text { Specifications for Hospital } \\
\text { Wastewater Treatment } \\
\text { Engineering (The } \\
\text { Specifications, HJ 2029- } \\
\text { 2013) }\end{array}$ & $\begin{array}{l}\text { Ministry of } \\
\text { Ecology and } \\
\text { Environment }\end{array}$ & 03/29/2013 & $\begin{array}{l}\text { Specify the wastewater treatment } \\
\text { process and disinfection measures } \\
\text { for medical wastewater from } \\
\text { hospitals dealing with infectious } \\
\text { diseases }\end{array}$ \\
\hline $\begin{array}{l}\text { General Rules for } \\
\text { Disinfection of Sites of } \\
\text { Epidemic Origin (GB 19193- } \\
\text { 2015) }\end{array}$ & $\begin{array}{l}\text { General } \\
\text { Administration } \\
\text { of Quality } \\
\text { Supervision, } \\
\text { Inspection and } \\
\text { Quarantine }\end{array}$ & 06/12/2015 & $\begin{array}{l}\text { Specify the requirements, } \\
\text { principles, and effects of } \\
\text { disinfection of sites of epidemic } \\
\text { origin }\end{array}$ \\
\hline $\begin{array}{l}\text { Emergency Monitoring } \\
\text { Program in response to } \\
\text { COVID-19 Outbreak (The } \\
\text { Monitoring Program) }\end{array}$ & $\begin{array}{l}\text { Ministry of } \\
\text { Ecology and } \\
\text { Environment }\end{array}$ & $01 / 31 / 2020$ & $\begin{array}{l}\text { Specify the emergency monitoring } \\
\text { of characteristic pollutants for } \\
\text { pandemic prevention and control } \\
\text { such as of chlorine residual and } \\
\text { biological toxicity }\end{array}$ \\
\hline $\begin{array}{l}\text { Notice on the Regulations of } \\
\text { Medical Wastewater and } \\
\text { Municipal Wastewater from } \\
\text { the COVID-19 Outbreak (The } \\
\text { Notice) }\end{array}$ & $\begin{array}{l}\text { Ministry of } \\
\text { Ecology and } \\
\text { Environment }\end{array}$ & $01 / 31 / 2020$ & $\begin{array}{l}\text { Specify the classification and } \\
\text { collection, monitoring, treatment, } \\
\text { and discharge requirements of } \\
\text { medical wastewater at the site of } \\
\text { the outbreak }\end{array}$ \\
\hline $\begin{array}{l}\text { Technical Program for } \\
\text { Emergency Treatment of } \\
\text { Medical Wastewater } \\
\text { Contaminated with Novel } \\
\text { Coronavirus (Trial)" (The } \\
\text { Technical Program) }\end{array}$ & $\begin{array}{l}\text { Ministry of } \\
\text { Ecology and } \\
\text { Environment }\end{array}$ & 02/01/2020 & $\begin{array}{l}\text { Strengthen the classification and } \\
\text { management of wastewater, and } \\
\text { enhance disinfection and } \\
\text { sterilization to meet the discharge } \\
\text { standards, and ultimately prevent } \\
\text { the spread of viruses. }\end{array}$ \\
\hline $\begin{array}{l}\text { Ecological Environmental } \\
\text { Monitoring Regulations } \\
\text { (Draft) (The Monitoring } \\
\text { Draft) }\end{array}$ & $\begin{array}{l}\text { Ministry of } \\
\text { Ecology and } \\
\text { Environment }\end{array}$ & $02 / 17 / 2020$ & $\begin{array}{l}\text { Clarify the responsible parties for } \\
\text { monitoring data, and strengthen } \\
\text { monitoring, reporting, and } \\
\text { reviewing }\end{array}$ \\
\hline
\end{tabular}

guarantee." A single device was able to provide the daily wastewater treatment capacity of 800-1000 
tons ${ }^{[15]}$. As shown in Figure 3, the tier-two protection and control system was composed of multiple processes including pre-disinfection, septic tank, conditioning tank, biological and chemical treatment (degradation of COD and ammonia nitrogen), sedimentation, and (secondary) disinfection. With the experience in medical wastewater treatment during SARS and the fact that E. coli, a COVID-19 microbial indicator, can be effectively killed by disinfection, the Huoshenshan Hospital implemented a safe, effective, and economical two-level intensified disinfection system ${ }^{[26]}$, i.e., pre-disinfection-septic tankdisinfection tank (secondary disinfection) ${ }^{[27]}$, lasting for 5 hours, much higher than the national standard of 1.5 hours ${ }^{[14]}$. This standard has been incorporated into the nationally implemented Design Guidelines for Emergency Treatment Facilities for COVID-19 (Trial) and the Design Standards for Emergency Medical Facilities for COVID-19 (T/CECS 661-2020) issued by the China Association for Engineering Construction Standardization.

Anaerobic degradation in the septic tank generally went through acidogenesis and methanogenesis during which organic wastewater and sewage of high concentrations were treated. This process produced low surplus sludge, which was easy to be concentrated and dewatered, while functioning as a disinfection process. The automatic mechanical screen removed debris that might negatively affect the system, such as tissue paper products ${ }^{[14]}$. The activated sludge method was a common biological treatment process, which removed organic pollutants in colloidal and dissolved forms in wastewater. Degraded organic matter and non-degraded pollutants existed in the sludge and were separated from the water through solid-liquid separation. Afterwards, the wastewater was disinfected to reach the specified standard and finally got discharged. With advantages of both traditional fluidized bed and contact oxidation process, the MBBR process effectively eliminated organic pollutants [28]; additionally, operation of the process was simple, with resistance to shock loads and low costs ${ }^{[29]}$. Therefore, MBBR was selected as the biological and chemical treatment technology for the hospital ${ }^{[23]}$. The sludge generated from the wastewater treatment was concentrated and dewatered and then transported to a centralized location for disposal. The odor from the wastewater treatment station was collected, disinfected, and then discharged. The sludge storage tank was disinfected with lime and bleach, and the sludge was removed using sealed centrifugal sludgers and mobile filter trucks. The sediment and sludge were disposed of and processed through incineration as hazardous waste ${ }^{[20]}$.

\section{Strict tier-three protection and control (deep disposal system)}

The treated wastewater was tested by the online monitoring station to make sure the water quality met the standards for medical wastewater pollutants specified in Table 1 (GB18466-2005) and then discharged into the municipal sewer system to finally reach the municipal wastewater treatment plant (Shiyang Wastewater Treatment Plant) for deep treatment. This is the tier-three prevention and control measure. At the wastewater treatment plants, water will be further treated to ensure the effluent reaches 
the standard for pollutants in the discharge of urban wastewater treatment plants (GB 18918-2002) before discharge ${ }^{[30]}$.

\section{Environmental monitoring management measures}

President Xi in China delivered encouraging instructions that "If Wuhan beats the pandemic, then Hubei province will succeed, and if Hubei defeats it, China will win." The Ministry of Ecology and Environment concentrated on the environmental monitoring of designated hospitals in Wuhan and swiftly formulated a "Monitoring Plan" (Table 1).

With field investigation, Wuhan Environmental Monitoring Center quickly drafted the Emergency Monitoring Program for COVID-19 Outbreak in Wuhan (hereinafter referred to as the Wuhan Monitoring Program) ${ }^{[31]}$, and mobilized relevant enterprises and monitoring units to provide real-time dynamic monitoring of the medical wastewater from 63 designated hospitals in the city, including the Huoshenshan Hospital, according to the program ${ }^{[32]}$. Conforming to the requirements of the Monitoring Program and the Wuhan Monitoring Program, monitoring of the medical wastewater of the Huoshenshan Hospital followed the three-tier accountability system of data monitoring, recording, and storage. Additionally, the Environmental Emergency Monitoring Information Briefing during the Prevention and Control of the Pandemic in Wuhan was prepared and submitted to higher-level monitoring authority for verification and record keeping. Environmental monitoring of medical wastewater quality during the epidemic also promoted the development of ecological and environmental big data platforms of China, formed a three-tier accountability system for monitoring the data collected from wastewater units, ecoenvironmental monitoring agencies, and general environmental monitoring stations (Figure 4), and established the legislative, scientific, and ethical foundations for the environmental monitoring system.

In order to perform real-time, dynamic tracking of the management and control of wastewater quality, the Huoshenshan Hospital was equipped with wastewater treatment facilities and online monitoring stations. Eco-environment division personnel conducted daily on-site inspection on the operation of pollution control facilities and checked discharge and monitoring data ${ }^{[10]}$. For discharge that did not meet the specified standards, they would perform step-by-step investigation to identify and solve the problems. Under strict monitoring and control measures, the monitoring work has also achieved a certain degree of success. The effluent water quality monitoring results of the wastewater treatment facilities at the Huoshenshan Hospital showed that from February 1 to February 21, 2020, levels of the characteristic indicators of the effluent from the wastewater treatment facility such as chlorine residual and fecal coliform were generally in conformance with the limits set in the Standards for the Discharge of Water

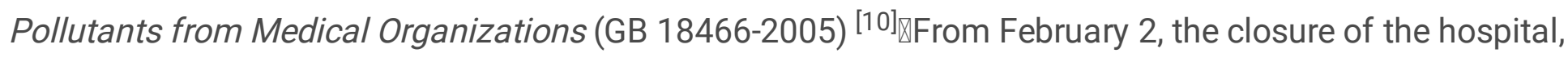
levels of characteristic indicators of the effluent have been controlled within the standard range ${ }^{34]}$, with chlorine residual reaching $6.5-10 \mathrm{mg} / \mathrm{L}$, a specified standard (GB 18466-2005) for the total chlorine residual at the outlet of a contact disinfection tank of hospitals treating infectious diseases. 


\section{Information disclosure and the role of public opinion supervision}

\section{Information disclosure and public participation}

The lack of information disclosure and public participation in public emergencies is one of the factors that hinder the development of environmental management. Therefore, the Ministry of Environmental Protection promulgated the Measures for Public Participation in Environmental Protection (Table 2) on June 13,2015 , to encourage and facilitate citizens, legal persons, and other organizations to exercise public opinion and social supervisions on public environmental affairs by legal means. With the development of internet technology, Chinese netizens have been playing an increasingly substantial role in public opinion supervision and management of environmental protection [ ${ }^{35]}$. According to the 46th Statistical Report on the Development of Internet in China by the China Internet Network Information Center (CNNIC), as of June 2020, the population of Chinese internet users has reached 940 million, the Internet penetration rate has grown to $67.0 \%$, and mobile users accounted for $99.2 \%$, providing a solid foundation for receiving and publishing information.

Information disclosure by government agencies is an important mean to obtain information for the general public, and it is also a prerequisite for public participation. During the pandemic, the Ministry of Ecology and Environment disclosed environmental information of the emergency to the public in accordance with the laws ${ }^{[5]}$, and reinforced the information disclosure on the medical wastewater of the Huoshenshan Hospital, providing relevant, accurate, and timely information to the public and social organizations. Therefore, it was ensured that the construction of medical wastewater treatment facilities and medical wastewater treatment data of the Huoshenshan Hospital were open and transparent.

Table 2

Laws, measures, and regulations regarding information disclosure and the public 


\begin{tabular}{|c|c|c|c|}
\hline Name & $\begin{array}{l}\text { Issuing } \\
\text { authority }\end{array}$ & $\begin{array}{l}\text { Issuing } \\
\text { date }\end{array}$ & Remarks \\
\hline $\begin{array}{l}\text { Emergency Regulations } \\
\text { for Public Health } \\
\text { Emergencies }\end{array}$ & State Council & $05 / 29 / 2003$ & $\begin{array}{l}\text { To establish a system of prompt } \\
\text { notification and timely information } \\
\text { release }\end{array}$ \\
\hline $\begin{array}{l}\text { Measures for } \\
\text { Environmental } \\
\text { Information Disclosure } \\
\text { (Trial) }\end{array}$ & $\begin{array}{l}\text { State } \\
\text { Environmental } \\
\text { Protection } \\
\text { Administration }\end{array}$ & 02/08/2007 & $\begin{array}{l}\text { To promote and specify the obligations } \\
\text { of environmental protection agencies } \\
\text { and enterprises to disclose } \\
\text { environmental information and protect } \\
\text { the rights and interests of citizens, } \\
\text { legal persons, and other organizations } \\
\text { to obtain environmental information }\end{array}$ \\
\hline $\begin{array}{l}\text { Management Measures } \\
\text { for Information } \\
\text { Disclosure of Medical } \\
\text { and Health Service } \\
\text { Organizations (Trial) }\end{array}$ & $\begin{array}{l}\text { Ministry of } \\
\text { Health }\end{array}$ & $06 / 03 / 2010$ & $\begin{array}{l}\text { To disclose information about medical } \\
\text { and health service organizations in } \\
\text { conformance with the laws and } \\
\text { improve the transparency of medical } \\
\text { and health service work }\end{array}$ \\
\hline $\begin{array}{l}\text { Notice of the Ministry of } \\
\text { Environmental } \\
\text { Protection on } \\
\text { Strengthening the } \\
\text { Information Disclosure } \\
\text { on Supervision of } \\
\text { Environmental Pollution } \\
\text { Sources }\end{array}$ & $\begin{array}{l}\text { Ministry of } \\
\text { Ecology and } \\
\text { Environment }\end{array}$ & $07 / 12 / 2013$ & $\begin{array}{l}\text { To protect the rights and interests of } \\
\text { citizens, legal persons, and other } \\
\text { organizations to obtain information of } \\
\text { environmental pollution sources using } \\
\text { legal means and issue guidance on } \\
\text { public participation in environmental } \\
\text { protection }\end{array}$ \\
\hline $\begin{array}{l}\text { Self-monitoring and } \\
\text { Information Disclosure } \\
\text { Measures for Key } \\
\text { Enterprises under State } \\
\text { Monitoring (Trial) }\end{array}$ & $\begin{array}{l}\text { Ministry of } \\
\text { Environmental } \\
\text { Protection }\end{array}$ & $07 / 30 / 2013$ & $\begin{array}{l}\text { To specify self-monitoring and } \\
\text { information disclosure for enterprises, } \\
\text { urge enterprises to intentionally fulfill } \\
\text { their legal obligations and social } \\
\text { responsibilities, and promote public } \\
\text { participation }\end{array}$ \\
\hline $\begin{array}{l}\text { The Environmental } \\
\text { Protection Law }\end{array}$ & $\begin{array}{l}\text { Standing } \\
\text { Committee of } \\
\text { the National } \\
\text { People's } \\
\text { Congress }\end{array}$ & $04 / 24 / 2014$ & $\begin{array}{l}\text { Enterprises and organizations shall } \\
\text { disclose environmental information } \\
\text { regarding environmental monitoring } \\
\text { and public emergencies in accordance } \\
\text { with the law; the public is entitled the } \\
\text { right to supervise environmental } \\
\text { protection issues }\end{array}$ \\
\hline $\begin{array}{l}\text { Measures for } \\
\text { Environmental } \\
\text { Information Disclosure } \\
\text { by Enterprises and } \\
\text { Organizations }\end{array}$ & $\begin{array}{l}\text { Ministry of } \\
\text { Environmental } \\
\text { Protection } \\
2014-12-19\end{array}$ & $12 / 19 / 2014$ & $\begin{array}{l}\text { Enterprises and organizations shall } \\
\text { accurately disclose environmental } \\
\text { information in accordance with the law; } \\
\text { public participation, supervision, and } \\
\text { management to be promoted }\end{array}$ \\
\hline $\begin{array}{l}\text { Measures for Public } \\
\text { Participation in } \\
\text { Environmental } \\
\text { Protection }\end{array}$ & $\begin{array}{l}\text { Ministry of } \\
\text { Environmental } \\
\text { Protection }\end{array}$ & $07 / 13 / 2015$ & $\begin{array}{l}\text { To protect the rights of citizens, legal } \\
\text { persons, and other organizations in } \\
\text { obtaining environmental information, } \\
\text { as well as participating in and } \\
\text { supervising environmental protection } \\
\text { issues; open up avenues for public } \\
\text { participation and promote the legal and }\end{array}$ \\
\hline
\end{tabular}




\section{Survey on public participation regarding the Huoshenshan Hospital}

Information release of the pandemic has been timely, accurate, open, and transparent. Netizens were not only receiving the open and transparent release of pandemic information but were also active supporters and protectors of this measure ${ }^{[36]}$. During the construction of the Huoshenshan Hospital, information was released online by government and state media $[37,38]$, and public participation became an important driver for orderly progression of the construction and wastewater management measures of the hospital. In the present study, a questionnaire survey was further applied to understand the breadth and depth of information disclosure about the hospital and its medical wastewater management, as well as the extent of public participation.

As shown in the survey results of questionnaire survey (Figure 5), most respondents were from Hubei province who were the nearest group to the case study. The respondents were characteristic of different ages stage and a wide range of educational background and occupation, while they focused on the students at the age of 18-30 years with bachelor degree. The results showed that young students with high education background are representative respondents for the case study. The findings also indicated that the majority of public (88\%) has paid close attention to the Huoshenshan Hospital (Figure 5). The surveyed individuals learned about it through multiple channels such as TV news, social media such as Weibo and WeChat, and Apps providing short videos to mobile users. This informed the audience of information disclosure. Majority of the public is able to actively utilize the well-developed Internet and a variety of web tools to receive widely public information on medical wastewater for the case hospital. It ensured enthusiasm and degree of participation of the public in the construction and wastewater management of the hospital to an extent. Concurrently, the requirement for broad public participation in the Measures for Environmental Information Disclosure (Trial) has been fulfilled.

One question in the survey asked the respondents to specify the primary way for them to participate in the public opinion supervision of the construction of wastewater facilities and wastewater management in the Huoshenshan Hospital. Most of them (67\%) indicated that they participated through following the news and comments on CCTV reports (Figure 7). The slow TV live broadcast of CCTV attracted 50 million "cloud supervisors" at the peak time [39], and overseas netizens also simultaneously watched the broadcast through YouTube and other foreign video websites [ ${ }^{40]}$. It revealed the enthusiasm, positivity, and high awareness involved in public participation. The survey results also showed that in the current information society, the general public can not only receive open information through all sorts of avenues, but also perform the public opinion supervision function through a variety of real-time, dynamic, and prompt approaches, such as publishing comments on official websites of relevant agencies, Weibo, and 
CCTV news websites/live broadcast platforms, contacting government officials through mails and hotlines, and commenting at WeChat official accounts.

\section{Comparison with developed countries}

Environmental Information Disclosure is a new tool for environmental governance in the era of big data and information ${ }^{[41]}$. Developed countries started earlier and achieved good results in this field while developing countries lagged relatively. Developed countries such as the EU member states, the US, and Japan have actively promoted public participation and have established related legal systems to emphasize the importance of and guarantee public participation and social supervision [ ${ }^{42]}$. For example, the US passed the National Environmental Policy Act as early as 1969, which for the first time established the status and rights of the public to participate in environmental impact assessment. The Basic Environment Law of Japan enacted in 1993 specified the avenues, procedures, and means of public participation. The Environmental Impact Assessment Law of 2003 of China defined public participation in environmental impact assessment of construction projects. Some recent studies have shown the positive effect of public participation in and supervision of environmental management on the mitigation of environmental degradation ${ }^{[43]}$. Although public legislation for public participation of China has been gradually improving, there is a demand for legislative and executive guarantees for public participation and environmental supervision regarding specific industries. To some extent, it impacted the width and depth of public participation. For example, there is no current legislation related to public participation in the medical wastewater management. Therefore, the case study on the Huoshenshan Hospital construction and wastewater management has provided an adequate reference to show the participation of netizens in public opinion supervision through a variety of network platforms and information tools, which displayed a big leap in the process compared to that in the SARS epidemic period. To fully utilize the positive effect of public opinion supervision in environmental management, efforts on two aspects are needed. The environmental system with information disclosure and transparency needs to be complemented and improved, and it is necessary to enhance the public awareness and promote the enthusiasm and motivation of netizens and NGOs to ultimately mobilize the public to take part in environmental management.

\section{Conclusions}

Through the case analysis of the Huoshenshan Hospital, we summarized some effective measures for the medical wastewater from hospitals treating infectious diseases, mainly in the following four aspects:

(1) Three-tier protection and control system was implemented for the emergency treatment of wastewater, through the steps of classification and collection from the ward, hospital wastewater treatment facilities, and municipal sewer system. Tier one focused on the pollution prevention at the source; tier two concentrated on the disinfection of the wastewater, and biological and chemical treatment of organic pollutants, to ensure the wastewater discharge met water quality standards. 
(2) Monitoring management mainly aimed to ensure effective operation of monitoring equipment, standardization of monitoring process, and providing timely, reliable, verifiable, and recordable monitoring data. The three-tier accountability system in the data monitoring process guaranteed authenticity of monitoring data and also promoted the construction and development of big data platforms.

(3) Medical Wastewater prevention and control technologies and measures were effectively implemented through the emergency legislative guarantee on the medical wastewater collection, monitoring, treatment, and discharge as well as the "Internet Plus" techniques.

(4) Results of the questionnaire survey confirmed that the majority of the public could follow the Huoshenshan Hospital updates through online tools such as TV news, Weibo, WeChat, and video-sharing apps for mobile users. They participated in online reviews and surveys of medical wastewater treatment facilities and management issues. It is recommended to further strengthen the disclosure of environmental information, improve public participation in industry-specific legislation, and promote public opinion supervision in managing and controlling medical wastewater.

\section{Abbreviations}

COVID-19: novel coronavirus pneumonia; MBBR: moving bed biofilm reactor; Tier one of source collection: prevention and control the source (source collection); tier-two of disposal system: Strict tiertwo protection and control (disposal system); Tire three of deep disposal system: Strict tier-three protection and control (deep disposal system); Wuhan Monitoring Program: Emergency Monitoring Program for COVID-19 Outbreak in Wuhan; CNNIC: China Internet Network Information Center.

\section{Declarations}

\section{Acknowledgements}

Not applicable.

\section{Author's contribution}

$\mathrm{HZ}$ designed the study and edit the tables and Figures, and together with JJH written the other partial original manuscript. SSZ analyzed the data and drawn the partial figures in Chinese. Other authors such as XYL, QL, WXF and CHS collected the study's information and associated with data.

\section{Funding}

This study was supported by the Ministry of Education Humanities and Social Sciences Research Projects (17YJC840013) and Scientific Research Projects of Education Department of Hubei Province (B2020053). 


\section{Availability of data and materials}

The complete dataset supporting the conclusion of this article is included within the article.

\section{Ethics approval and consent to participate}

Not applicable.

\section{Consent for publication}

All the authors read and approved this paper.

\section{Conflict of Interest}

The authors declare that they have no conflict of interest.

\section{Author details}

${ }^{1}$ School of Management, Wuhan Institute of Technology, 430205, Wuhan, China

${ }^{2}$ School of Chemistry and Environmental Engineering, Wuhan Institute of Technology, 430205 Wuhan, China.

\section{References}

1. Achak M, Alaoui SB, Chhiti Y, et al (2021). SARS-CoV-2 in hospital wastewater during outbreak of COVID-19: a review on detection, survival and disinfection technologies. Sci Total Environ 761: 143192.

2. Delisle Jacques (2003) SARS, Greater China, and the Pathologies of Globalization and Transition. Orbis 47(4): 587-604.

3. Cristina P, Beatriz V, Gisela R et al (2020) COVID-19 infodemic: More retweets for science-based information on coronavirus than for false information. Int Sociol 35(1): 377-392.

4. Bandala ER, Kruger BR, Cesarino I et al (2021) Impacts of COVID-19 pandemic on the wastewater pathway into surface water: A review. Sci Total Environ 774: 145586.

5. Kang A, Ren L J, Hua C Y et al (2021) Environmental management strategy in response to COVID-19 in China: Based on text mining of government open information. Sci Total Environ 769: 145158.

6. Zhao YN (2020) China's air, water quality unaffected by epidemic: ministry. Beijing: China News 2020-02-23. http://www.ecns.cn/news/society/2020-02-23/detail-ifztvsqr0575681.shtml. 
7. Mounia A, Soufiane AB, Younes Cet al (2021) SARS-CoV-2 in hospital wastewater during outbreak of COVID-19: A review on detection, survival and disinfection technologies. Sci Total Environ 761: 143192.

8. Wang J, Shen J, Ye D et al (2020) Disinfection technology of hospital wastes and wastewater: Suggestions for disinfection strategy during coronavirus Disease 2019 (COVID-19) pandemic in China. Environ Pollu 262:114665.

9. Achak M, Bakri SA, Chhiti Y et al (2021) SARS-CoV-2 in hospital wastewater during outbreak of COVID-19: A review on detection, survival and disinfection technologies. Sci Total Environ 761: 143192.

10. Basturka I, Varankb G, Murat-Hocaoglua S et al (2020) Characterization and Treatment of Medical Laboratory Wastewater by Ozonation: Optimization of Toxicity Removal by Central Composite Design. Ozone Sci Eng 43(3): 1794794. https://doi.org/10.1080/01919512.

11. Zhao L , Atoni E, Nyaruaba R et al (2022) Environmental surveillance of SARS-CoV-2 RNA in wastewater systems and related environments in Wuhan: April to May of 2020. J Environ Sci 112: 115-120.

12. Sampriti K, Soumya C, Mohan G et al (2021) Concerns and strategies for wastewater treatment during COVID-19 pandemic to stop plausible transmission.Resour Conserv Recycl 164: 105156.

13. Yan S, Zhang XL, Tyagi RD et al (2020) Current Developments in Biotechnology and Bioengineering 1st Edition Environmental and Health Impact of Hospital Wastewater : 16 - Guidelines for hospital wastewater discharge. 571-597. https://doi.org/10.1016/B978-0-12-819722-6.00016-X.

14. Sun N, Wu SZ, Hou GG (2007) Implementation Status, Barriers and Suggestions on National Construction Planning of Medical Waste Disposal Facilities . J Environ Sci 20 (3): 158-163.

15. Huang YH (2020) A full decryption of medical wastewater on Leishenshan Hospital and Huoshenshan Hospital. Beijing: China Environmental News 2020-02-04. https://news.china.com/zw/news/13000776/20200204/37763381_all.html.

16. Wang QT (2020) How to deal with the medical sewage from Huoshenshan Mountain Hospital $\mathbb{Z}$ Beijing: China Environmental News 2020-02-

11. https://www.cenews.com.cn/newpos/xf/202002/t20200211_927741.html.

17. LI Y (2020) Wuhan achieves full disposal of medical waste, wastewater. Beijing: China News, 202003-30. http://www.ecns.cn/news/society/2020-03-30/detail-ifzuwwmz9244892.shtml.

18. Cheng M (2020) Xinhua Headlines: China builds new hospital in 10 days to combat coronavirus. Xinhua News 2020-02-02.http://www.xinhuanet.com/english/2020-02/02/c_138750364.htm.

19. Williams S (2020) Coronavirus: how can China build a hospital so quickly? 2020-04-05. https://www.bbc.com/news/world-asia-china-51245156.

20. Xiao YX (2020) "Houshenshan Hospital" -Which was built in 10 days. Xinhua News 2020-0203. http://www.xinhuanet.com/politics/2020-02/03/c_1125523730.htm.

21. Qingni Ma (2020) Two mountains hospitals (Huoshenshan Hospital \& Leishenshan Hospital) won the National Innovation Award as the international leader of key technologies in fast building 
medical hospital of. Wuhan: Chutian Metropolis Daily 2020-06-

11. http://www.ctdsb.net/html/2020/0611/hubei313631.html.

22. Al Aukidy M., Al Chalabi S., Verlicchi P (2020) Hospital Wastewater Treatments Adopted in Asia, Africa, and Australia . Hospital Wastewaters 171-188.

23. Verlicchi P et al (2015) "What have we learned from worldwide experiences on the management and treatment of hospital effluent? - An overview and a discussion on perspectives." Sci Total Environ 514: 467-491.

24. Gormley, M., Aspray, TJ, Kelly, DA (2020) COVID-19: mitigating transmission via wastewater plumbing systems [J]. The Lancet Global Health, 8(5): 643. DOI: 10.1016/S2214-109X (20)30112-1.

25. Chuanzhi L, Zhang F, Yu YG (2020) Discussion on the safety design of pneumonia infectious disease hospital drainage system in Vulcan Mountain. Water supply and drainage 1-

12. http://kns.cnki.net/kcms/detail/11.4972.tu.20200222.1730.004.html.

26. Wang J, Shen J, Ye D et al (2020) Disinfection technology of hospital wastes and wastewater: Suggestions for disinfection strategy during coronavirus Disease 2019 (COVID-19) pandemic in China. Environ Pollut 262: 114665.

27. Xia H (2020) Wuhan disinfects drainage, sewage disposal facilities. Beijing: Xinhua News, 2020-0220. http://www.xinhuanet.com/english/2020-02/20/c_138801836.htm

28. Li CZ, Zhang F, Liu B (2020) Discussion on biochemical treatment process design of sewage treatment of Huoshenshan COVID-19 infectious disease hospital. Water \& Wastewater Engineering 46(4): 25-31.

29. KMS Hansen, A Spiliotopoulou, RK Chhetri, et al (2016) Ozonation for source treatment of pharmaceuticals in hospital wastewater - Ozone lifetime and required ozone dose. Chem Eng J 290: 507-514.

30. Xu HB (2020) Wuhan Huoshenshan Hospital and Leishenshan Hospital were officially closed drainage pipeline has been basically completed. Beijing: Xinhua News 2020-0130. http://m.xinhuanet.com/hb/2020-01/30/c_1125512893.htm.

31. Wuhan Municipal Bureau of Ecological Environment (2020) Everyone in the war against the "epidemic"-- to guard the ecological and environmental protection defense line against the spread of the virus. Wuhan『Wuhan Municipal Bureau of Ecological Environment 2020-03-05. http://hbj.wuhan.gov.cn/hjxw/202004/t20200416_1019431.html.

32. The Ministry of Ecology and Environment (2020) Record of the regular press conference of the Ministry of Ecology and Environment in May. Beijing: The Ministry of Ecology and Environment: 2020-03-11. http://www.gov.cn/xinwen/2020-03/11/content_5489980.htm.

33. The Ministry of Ecology and Environment (2020) The Ministry of Ecology and Environment announced the progress of the key work of ecological and environmental protection and answered questions on ecological and environmental monitoring. Beijing: The Ministry of Ecology and Environment: 2020-06-03. http://www.gov.cn/xinwen/2020-06/03/content_5516939.htm. 
34. Lu Y (2020) Huoshenshan Hospital and Leishenshan Mount Hospital were officially closed. Beijing $\searrow$ China News Network 2020-4-15. https://www.chinanews.com/sh/2020/04-15/9158058 htm.

35. Wu JN, Xu MM, Zhang P (2018) The impacts of governmental performance assessment policy and citizen participation on improving environmental performance across Chinese provinces. J Clean Prod 184: 227-238.

36. Beijing Youth Daily (2020) To release the information on epidemic in a timely and accurate manner so as to enhance public trust . Beijing Youth Daily, Beijing: 2020-01-27. http://epaper.ynet.com/html/2020-01/27/content_347863.htm?div=-1.

37. Xiao YJ (2020) Construction of Huoshenshan Hospital underway in Wuhan. Beijing: Xinhua News 2020-01-29. http://www.xinhuanet.com/english/2020-01/29/c_138740524.htm\#

38. Ma Yujie (2020) Xinhua Headlines: Quiet and busy -- Lunar New Year's Eve in Wuhan, center of coronavirus fight. Beijing: Xinhua News, 2020-01-25. http://www.xinhuanet.com/english/202001/25/c_138733435.htm.

39. Wenjuan Zhang. Under the epidemic situation, why does slow live broadcast become "hot style"-Take the Huoshenshan Hospital as an example of slow live broadcast. Young journalist, 2020 (14): 8-9.

40. Zhi YJ (2020) To watch the live broadcast on the Chinese fast-- finishing the hospital in 10 days, this won the plaudits from foreign media and overseas netizens. Beijing $\mathbb{C C C T V}$ international online. http://news.cnr.cn/native/gd/20200205/t20200205_524961842.shtml.

41. Li YS, Zhang XJ, Yao TT et al (2021). The developing trends and driving factors of environmental information disclosure in China. J Environ Mange 288: 112386.

42. Liu HT (2014) Current Situation, Characteristics and Promotion of Public Participation and Social Supervision on Foreign Environmental Protection Legislation. J Environ Sci Mange 39 (12): 25-28. DOI:10.3969/j.issn.1673-1212.2014.12.006.

43. Yao XY, J HE, Bao CK (2020) Public participation modes in China's environmental impact assessment process: An analytical framework based on participation extent and conflict level. Environ Impact Assess Rev 84: 106400.

\section{Figures}




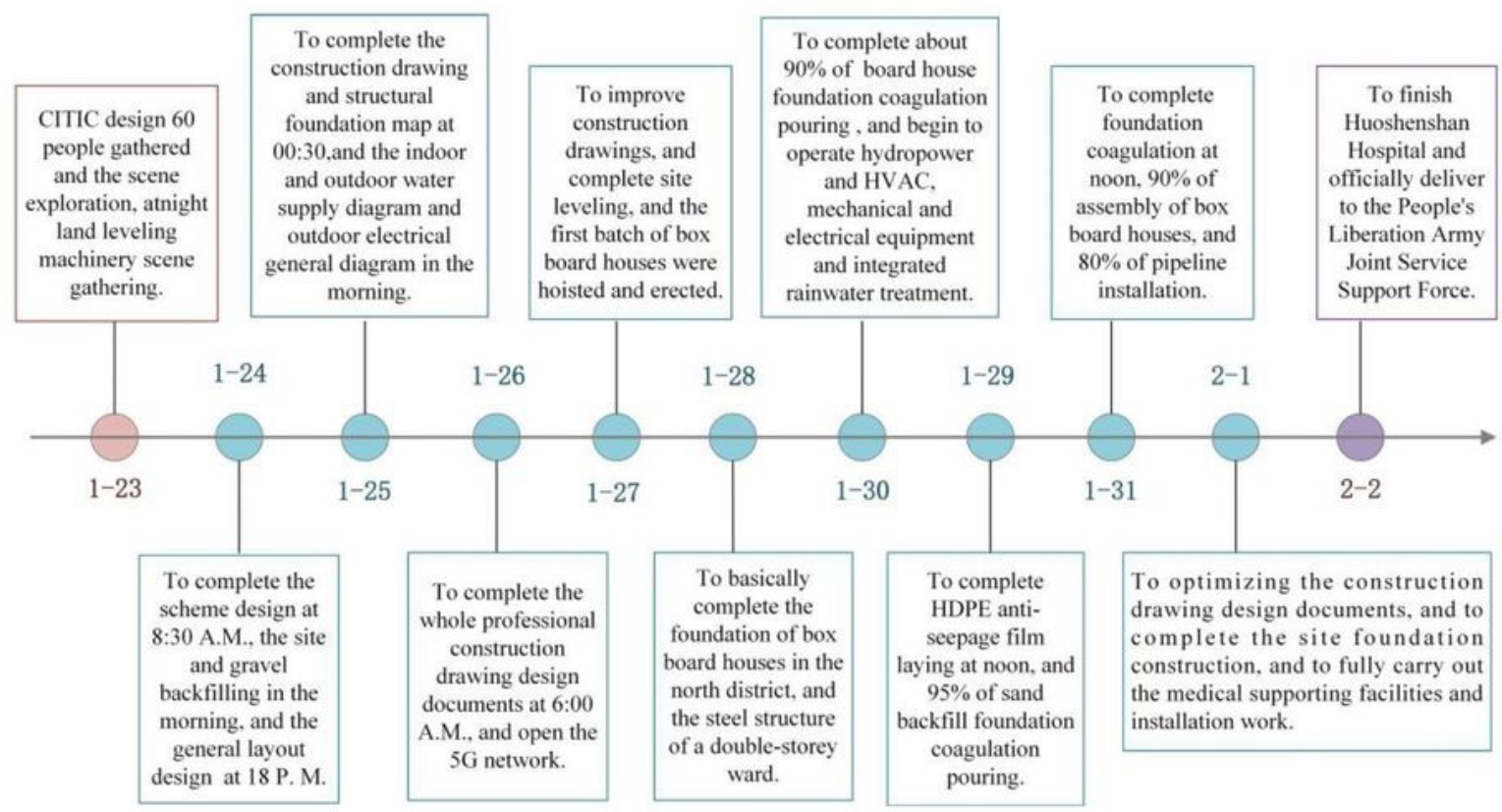

(a) Construction progress of the hospital by time

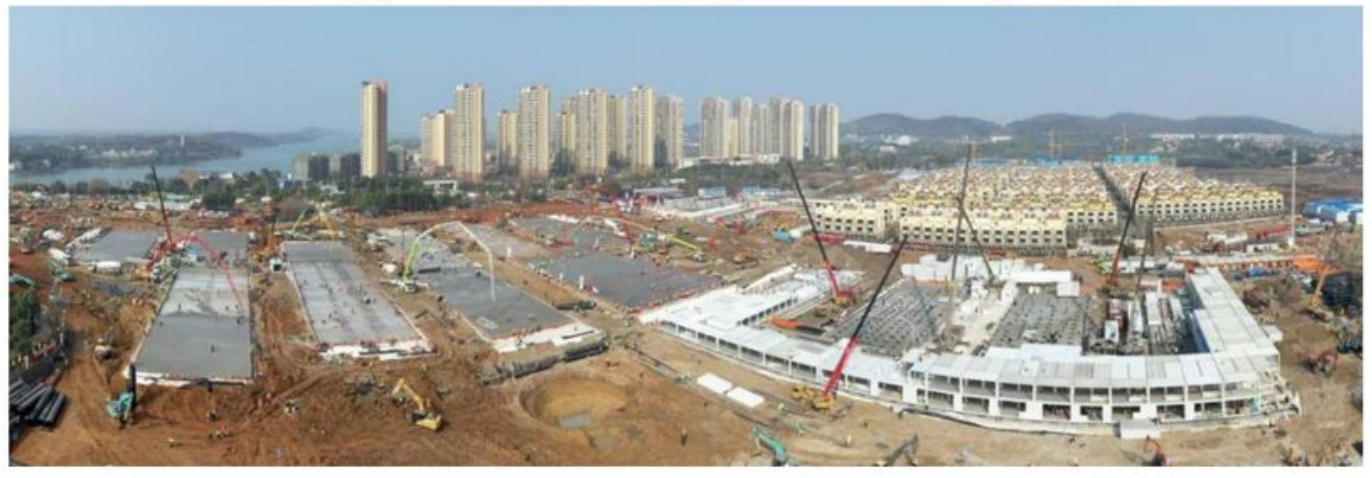

(b) Construction site on January 29

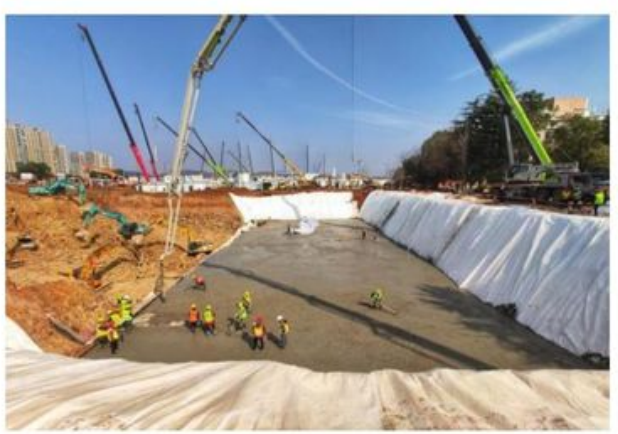

(c) Construction site on January 30

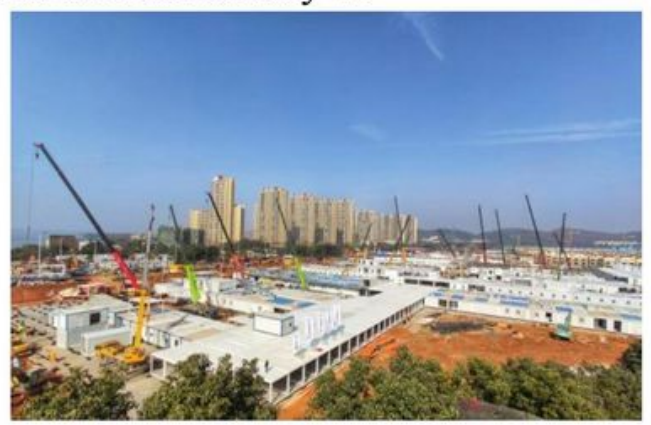

(d) Construction site on January 31

\section{Figure 1}

Construction progress of the Huoshenshan Hospital Note: Images were taken from the official website of CITIC General Institute of Architectural Design \& Research Co. with permission. The light bule circles (in total nine) in the Figure 1 (a) indicate the construction process. 


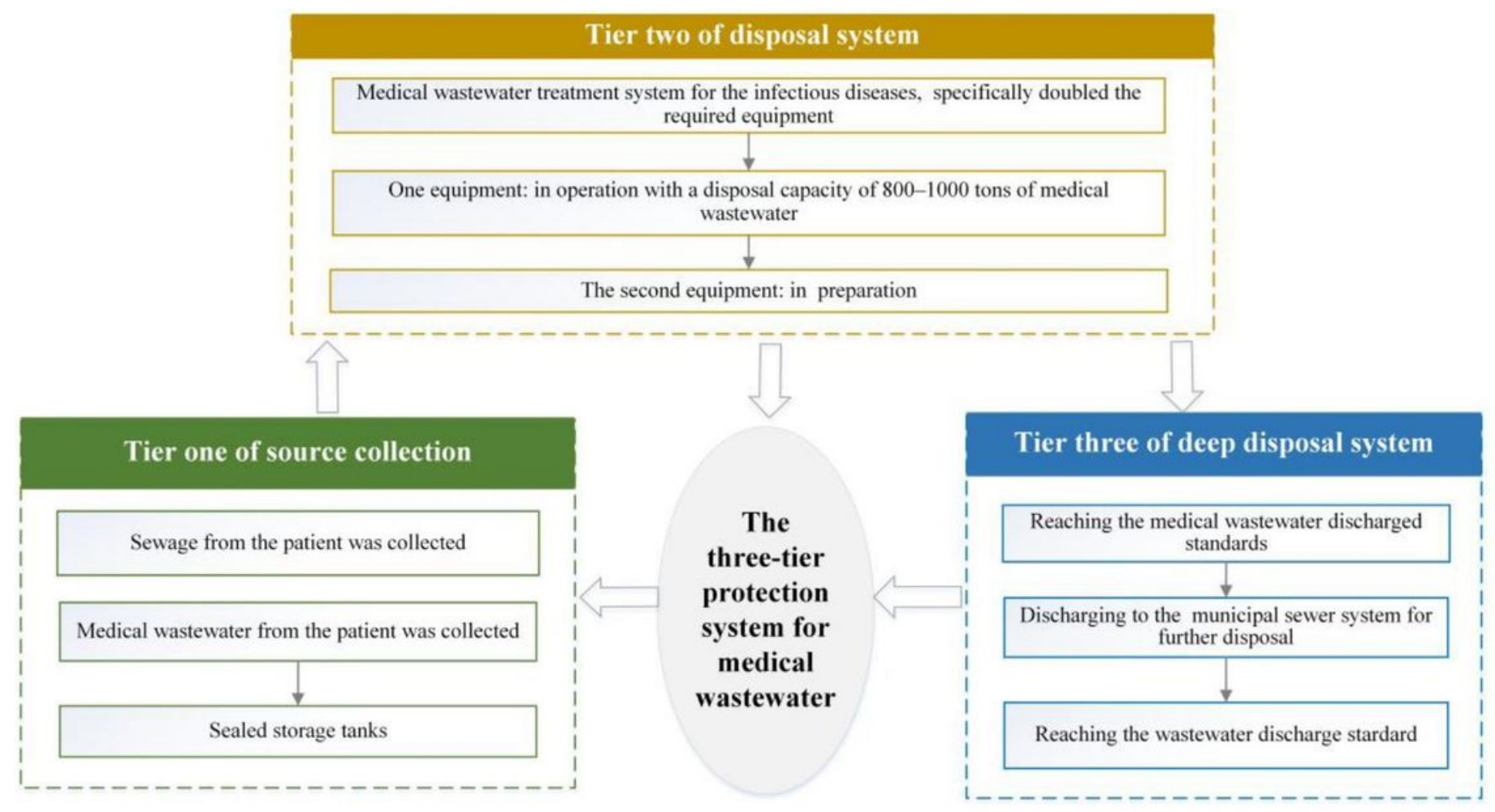

\section{Figure 2}

General diagram of the three-tier protection system

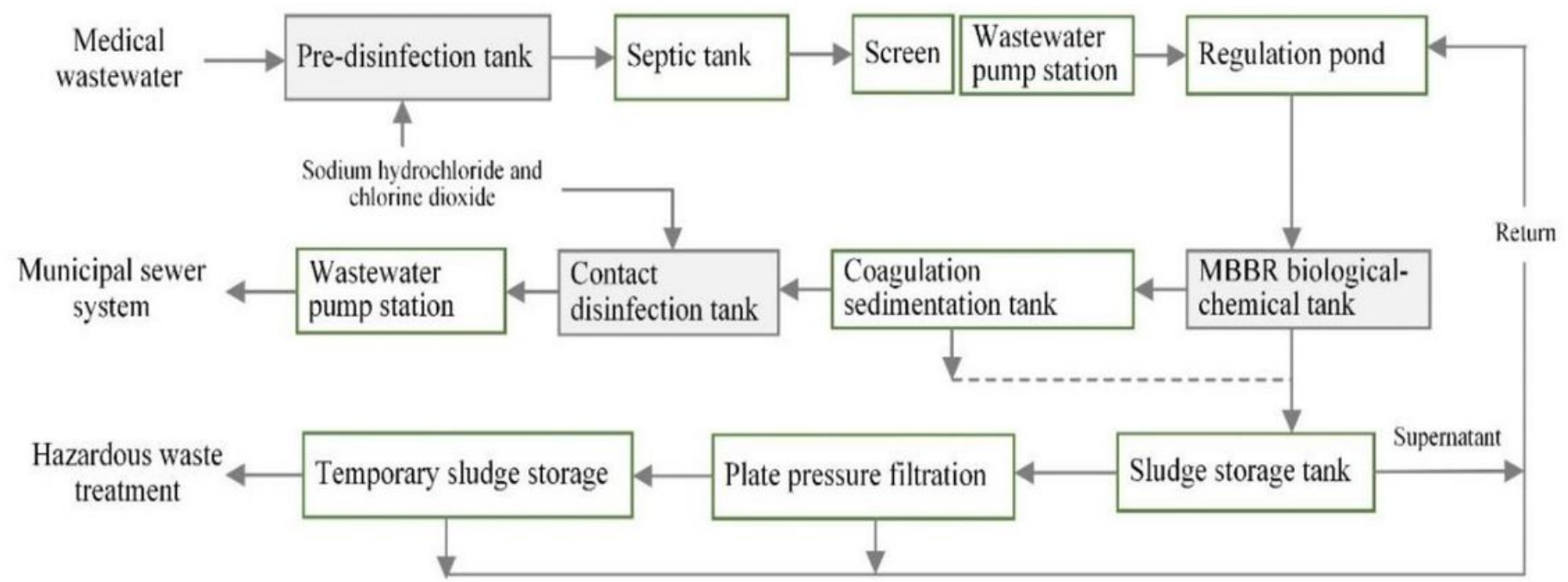

\section{Figure 3}

Treatment process of medical wastewater for Huoshenshan Hospital 


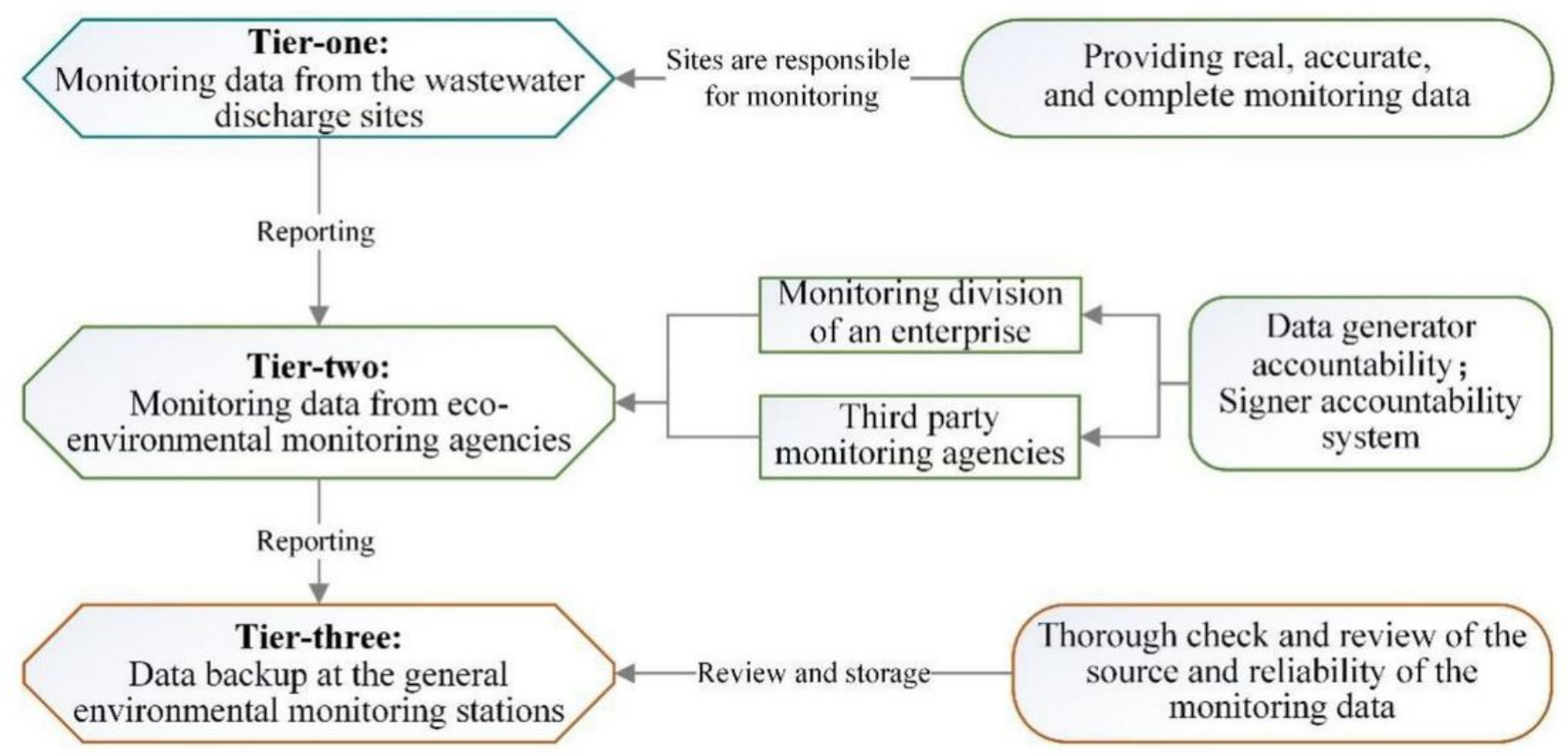

Figure 4

Monitoring data tracking chart [ 12 ] 
Q1: Are you from Hubei province?

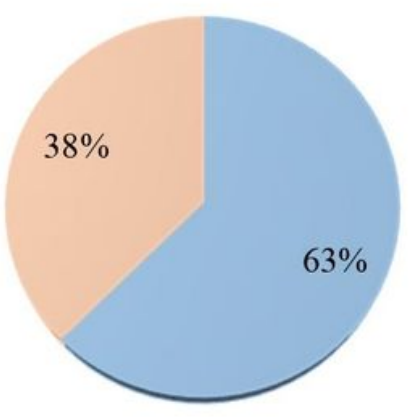

Q3: What is your educational background?

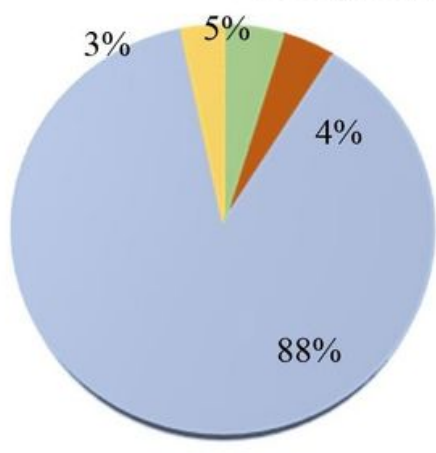

Q2: What is your age?

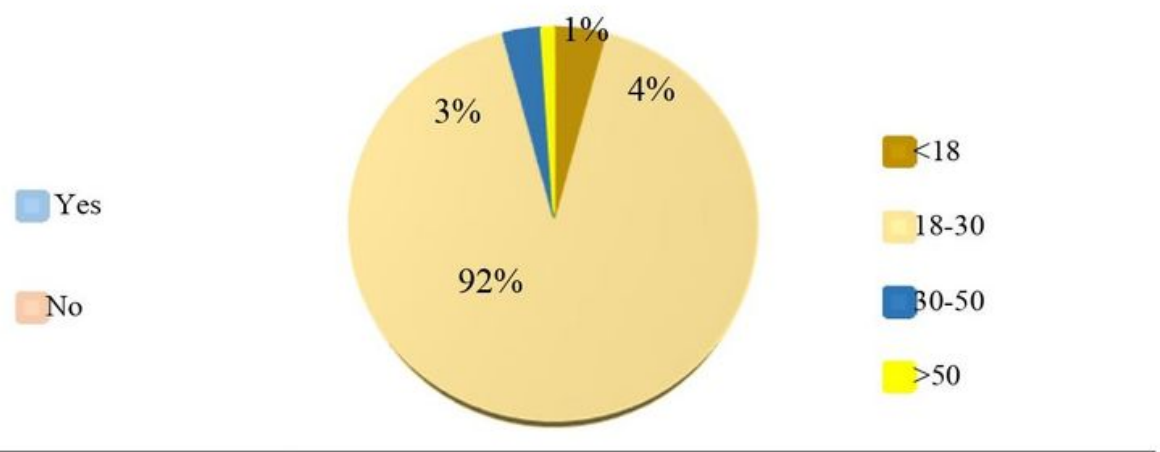

Q4: What is your occupation?

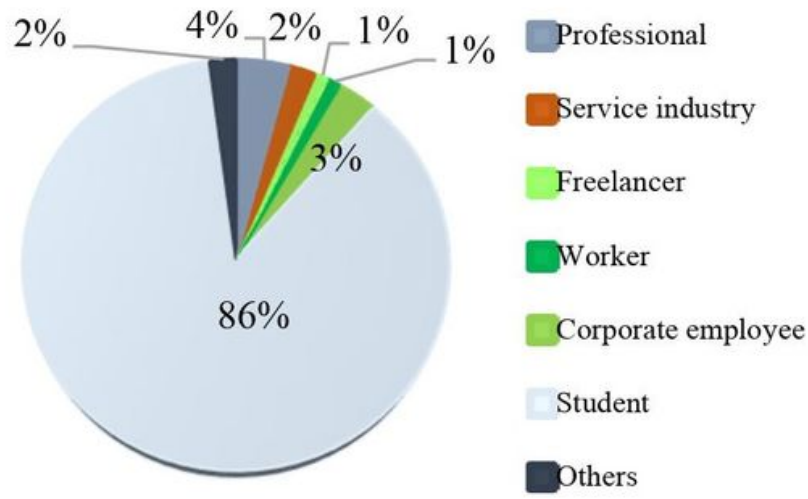

\section{Figure 5}

Characterization of survey respondents

\begin{tabular}{|c|c|c|c|c|c|c|}
\hline \multicolumn{3}{|c|}{$\begin{array}{l}\text { Q5: Have you followed news } \\
\text { regarding the Huoshenshan } \\
\text { Hospital? }\end{array}$} & \multicolumn{4}{|c|}{$\begin{array}{l}\text { Q6: How did you get information regarding } \\
\text { the Huoshenshan Hospital? }\end{array}$} \\
\hline $100 \%$ & $11.9 \%$ & & $80 \%$ & & & \\
\hline $80 \%$ & & & $60 \%$ & & & \\
\hline $60 \%$ & & No & $40 \%$ & & & \\
\hline $40 \%$ & $88.1 \%$ & Yes & $\begin{array}{l}20 \% \\
0 \%\end{array}$ & & & \\
\hline $20 \%$ & & & $\begin{array}{l}=\mathrm{TV} \\
=\mathrm{We} \\
=\mathrm{Ne}\end{array}$ & $\begin{array}{l}\text { news } \\
\text { Chat } \\
\text { Nspaper }\end{array}$ & $\begin{array}{l}\text { Weibo } \\
\text { Video-sharing apps } \\
\text { Others }\end{array}$ & $\begin{array}{l}\text { Bilibili website } \\
\text { Other people }\end{array}$ \\
\hline
\end{tabular}

Figure 6 


\begin{tabular}{|c|c|c|}
\hline $\begin{array}{l}\text { Q7: How did you participate in the public opinion } \\
\text { supervision of the construction and management of }\end{array}$ & $100 \%$ & $\begin{array}{l}\text { Q8: Which choice can enable the public to exercise } \\
\text { their rights in public opinion supervision? }\end{array}$ \\
\hline $6.6 \%$ & $80 \%$ & \\
\hline & $40 \%$ & \\
\hline Following and commenting on the relevant CCTV news reports & $0 \%$ & Commenting on the official websites of relevant agencies \\
\hline Online monitoring of the re-construction to repair leaks caused by extreme weather & & Weibo public opinion supervision \\
\hline Following the construction of the Huoshenshan Hospital and the medical wastewater man & & $\begin{array}{l}\text { Mayor's Mailbox and hotlines } \\
\text { Mailor }\end{array}$ \\
\hline Actively fill in the relevant online questionnaires & & Tipping the news media \\
\hline Following the relevant news conference held by the government agencies of Hubei provin & & Comment field of WeChat official accounts \\
\hline Others & & $\begin{array}{l}\text { Participating in NGO activities } \\
\text { Others }\end{array}$ \\
\hline
\end{tabular}

\section{Figure 7}

Survey on how the general public exercised their rights in public opinion supervision 